\title{
PENGARUH KUALITAS PRODUK TERHADAP KEPUTUSAN KONSUMEN MEMBELI PRODUK OLI PT. JPI KOTA PALU
}

\author{
Rani Agung $\mathbf{S}$ \\ Wahyuningsih dan Rahmat Mubaraq \\ Program Studi Manajemen S1, Fakultas Ekonomi Dan Bisnis Universitas Tadulako \\ Email : raniagung07@gmail.com \\ Abstrack
}

Rani Agung, effect of product quality on consumer decisions to buy oil products produced by PT. Jumbo Power Internasional in the city of Palu. Guided by Wahyuningsih and Rahmat Mubaraq. The purpose of this study was to determine and analyce the simultancous and partial influence on the effect of product quality and the decision of consumer to buy oil from PT. Jomblo Power Internasional in the city of Palu. The number of samples in this study were 120 respondents. Data collection techrigues used were observation, interviews, questionnaires, and ducumentation. The rescarch method uses Axidental sampling, besides the measurement scale in this study is the liker scale and analysis used is multiple linear regression analysis. The results of this study are product quality variables consisting of performance, retiability, durability, aeshetics, perceived quality, additional privileges, and conformity to specifications simultaneously and partially have a sinificant effect on the consensus decision of buying oil product produced by PT. Jumbo Power Internasional in the city of Palu.

Key words : product quality (performance, retiability, durability, aeshetics, perceived quality, additional privileges, and conformity to specifications) consumer decisions

Abstrak

RANI AGUNG, Pengaruh kualitas produk terhadap keputusan konsumen membeli produk oli produksi PT. Jumbo Power Internasional di kota Palu, di Bimbing oleh Wahyuningsih dan Rahmat Mubaraq.

Tujuan penelitian ini adalah untuk mengetahui dan menganalisis pengaruh simultan dan parsial terhadap pengaruh kualitas produk dan keputusan konsumen membeli oli produk PT. Jumbo Power Internasional di Kota Palu. Adapun jumlah sampel pada penelitian ini yaitu 120 responden. Teknik pengumpulan data yang digunakan adalah observasi, wawancara, kuisioner, dan dokumentasi. Metode penelitian menggunakan Aksidental sampling, selain itu skala pengukuran dalam penelitian ini adalah skala Liker dan analisis yang digunakan yaitu analisis regresi linear berganda. Hasil penelitian ini adalah variabel kualitas produk yang terdiri dari kinerja, kehandalan, daya tahan estetika, kualitas yang dipersepsikan, keistimewaan tambahan dan kesesuaian dengan spesifikasi secara simultan dan parsial berpengaruh signifikan terhadap keputusan konsumen membeli produk oli produksi PT. Jumbo Power Internasional di Kota Palu.

Kata kunci: kualitas produk (kinerja, kehandalan, daya tahan estetika, kualitas yang dipersepsikan, keistimewaan tambahan dan kesesuaian dengan spesifikasi), keputusan konsumen

\section{PENDAHULUAN}

Seiring dengan pertumbuhan ekonomi yang sangat pesat saat ini, maka dapat dilihat bahwa sektor dunia usaha saat ini telah menjadi salah satu arena persaingan yang sengit dan tiada henti-hentinya bagi perusahaan-perusahaan yang berperan didalamnya. Oleh karena itu, perusahaan dituntut agar lebih mampu memahami permintaan konsumen secara total sehingga dapat mencapai tujuan perusahaan dalam menjalankan bisnisnya. Di era globalisasi yang semakin maju ini, ada banyak hal yang harus dilakukan para produsen agar dapat bersaing di pasar dan mampu mendapatkan konsumen yang setia, diantaranya produsen harus mempu menciptakan kualitas produk yang baik dan mampu 
memberikan manfaat yang lebih bagi konsumen. Kualitas produk merupakan salah satu komponen yang mempengaruhi keputusan pembelian konsumen, sehingga hal ini merupakan pemahaman bahwa produk yang ditawarkan oleh penjual mempunyai nilai jual yang lebih dan tidak di memiliki oleh produk pesaing.

Begitu juga semakin banyak bermunculan oli pelumas mesin dengan berbagai merek sehinggan mengharuskan perusahaan untuk lebih meningkatkan kualitas produk yang mereka hasilkan. Salah satu produk pelumas yang diminati konsumen di Kota Palu yaitu Oli Jumbo Power Internasional dengan melihat meningkatnya hasil penjualan pada kantor cabang Kota Palu.

Oli Jumbo merupakan salah satu pelumas mesin kendaraan yang di produksi oleh PT. Jumbo Power Internasional. Perusahaan ini di dirikan pada tahun 1980 sebagai perusahaan yang bergerak dibidang importer dan trading, dimana produk yang ditangani pada saat itu adalah Spare-parts dan Accu kendaraan bermotor. Pada tahun 1990 perusahaan ini terus berkembang dan mampu mendirikan perusahaan sendiri serta mulai melakukan kegiatan produksi (Jumbopower.com).

Selain itu, di saat penjualan oli lesu, justru PT. Jumbo Power International selaku produsen produk oli dan minyak rem 'Jumbo' mengalami peningkatan. Tercatat, diakhir tahun 2012 s.d 2015 ini Jumbo semakin agresif dalam melakukan penjualan produk oli dan minyak rem diseluruh Indonesia.

Salah satu produk pelumas yang diminati konsumen di Kota Palu yaitu Oli Jumbo Power Internasional dengan melihat meningkatnya hasil penjualan pada kantor cabang Kota Palu.Power Internasional. Perusahaan ini di dirikan pada tahun 1980 sebagai perusahaan yang bergerak dibidang importer dan trading, dimana produk yang ditangani pada saat itu adalah Spare-parts dan Accu kendaraan bermotor. Pada tahun 1990 perusahaan ini terus berkembang dan mampu mendirikan perusahaan sendiri serta mulai melakukan kegiatan produksi (Jumbopower.com).Selain itu, di saat penjualan oli lesu, justru PT. Jumbo Power International selaku produsen produk oli dan minyak rem 'Jumbo' mengalami peningkatan. Tercatat, diakhir tahun 2012 s.d 2015 ini Jumbo semakin agresif dalam melakukan penjualan produk oli dan minyak rem diseluruh Indonesia. Hampir semua distribusi penjualan nasional di tangani sendiri oleh Jumbo Power International, yang memiliki 56 cabang diseluruh Indonesia. Kota palu merupakan salah satu tempat pemasaran Oli pelumas Jumbo Power Internasional dan memiliki kantor cabang pemasaran yang berada di jalan I ngusti ngurarae, No. 65 Palu Sulteng. Kantor ini bergerak dibidang distributor produk-produk yang di Produksi Perusahaan inti PT. Jumbo Power Internasional. Tidak heran Jumbo punya target yang realistis mengingat kebutuhan masyarakat terhadap oli dan minyak rem terus mengalamai peningkatan. "Target tahun depan untuk penjualan oli Jumbo X-Cool series diharapkan mengalami pertumbuhan yang cukup tinggi, karena jenis oli ini sangat diminati masyarakat di kota besar, terutama Jakarta, Bandung, Surabaya, Makassar dan lainnya. Bukan itu saja, semua produk oli dan minyak rem Jumbo sudah teruji kualitasnya untuk kendaraan jenis mobil dan motor. Dengan begitu konsumen merasa nyaman mengganti olinya dengan merek Jumbo.

\section{KAJIAN LITERATUR DAN PENGEMBANGAN HIPOTESIS Pengertian Pemasaran}

Pemahaman terhadap aktivitas pemasaran diawali dengan adanya kenyataan bahwa manusia memiliki lebih banyak kebutuhan dan keinginan. Kebutuhan serta keinginan konsumen inilah yang menjadi bentuk sasaran terhadap aktivitas pemasaran. Dengan demikian aktivitas pemasaran merupakan salah satu aktivitas yang sangat penting dalam suatu kegiatan perusahaan. Kata lain, semakin berhasil suatu kegiatan pemasaran yang dilakukan oleh sebuah perusahaan, maka semakin berkembang pula usaha tersebut. Aktivitas pemasaran merupakan salah satu dari kegiatan pokok yang 
digunakan oleh para pembisnis dalam usahanya guna untuk mempertahankan kelangsungan dalam hidupnya, untuk lebih maju dan mendapatkan keuntungan. Tanggapan Kotler serta Keller (2009:5) bahwa penyampai barang ialah suatu bentuk kemanusian yang dimana sendiri atau bergerombol menperoleh apa yang mereka butuhkan dan memperoleh dengan membuat, menawarkan dan secara lepas mempertukarkan barang dan jasa yang memiliki nilai dengan orang lain. Menurut American Marketing Association (AMA) dalam Kotler dan Keller (2009:5) pemasaran adalah suatu fungsi organisasi dan serangkaian proses untuk menciptakan, mengomunikasikan, dan memberikan nilai kepada pelanggan dan untuk mengelola hubungan pelanggan dengan cara menguntungkan organisasi dan pemangku kepentingannya. Nystrom dalam Samsinar (2010:12) aktivitas pemasaran meliputi semua kegiatan yang mengenai penyaluran terhadap barang atau jasa dari tangan produsen atau pembuat ke tangan pembeli atau konsumen.

\section{Pengertian Manajemen Pemasaran}

Dipahami atau tidak untuk hari ini aktivitas penyampai barang sudah mempengaruhi segenap aspek di dalam kehidupan manusia sehari-hari, baik itu langsung maupun tak langsung. Peran pemasar sangat penting guna untuk membantu pabrik agar mencapai harapan karena aktivitas perusahaan diarahkan untuk membuat pertukaran yang memungkinkan pabrik dapat mempertahankan kelangsungan hidup serta berkembang dan menghasilkan pendapatan yang besar.

Salah satu karakteristik penting dari aktivitas penyampai barang sebagai salah satu usaha yaitu fokusnya pada pelanggan dan pada kebutuhan konsumen. Apabila dikerjakan dengan waktu tepat, pemusatan perhatian semacam itu memungkinkan perusahaan menikmati keberhasilan sepanjang waktu dengan mengeksploitasi perubahan-perubahan pasar dan mengembangkan produk-produk yang dapat menunjukkan keunggulan dibandingkan apa yang ada pada saat ini. Manajemen pemasaran merupakan salah satu aktivitas dalam bentuk bisnis yang bertujuan untuk merencanakan, mengimplemantasikan (yang terdiri dari kegiatan mengorganisasian, mengarahkan, mengkoordinir) serta pengawasan atau mengendalikan aktivitas pemasaran dalam suatu lembaga agar tercapainya tujuan perusahaan secara efektif dan efesien.

Menurut American Marketing Association dalam Kotler dan Keller, (2009: 5), mendefenisikan antara karya serta ilmu untuk memilih tempat tujuan dan meraih, mempertahankan, serta menumbuhkan pembeli serta menciptakan, menghantarkan, dan mengkomunikasikan hasil pembeli yang utama.

\section{Pengertian Bauran Pemasaran}

Pengertian bauran pemasaran atau marketing mix adalah merupakan salah satu nilai konsep pertama dalam aktivitas pemasaran sekarang. Bauran pemasaran mempunyai peran yang sangat penting dalam mempengaruhi pelanggan untuk membeli prodak dan jasa yang ditawarkan oleh perusahaan. Menurut Kotler dan Keller (2009:18) bauran pemasaran adalah sekumpulan alat aktivitas pemasaran yang dibutuhkan perusahaan untuk terus mencapai suatu tujuan pemasarannya yang ada di tempat yang akan di tuju. Defenisi lain mengenai bauran pemasaran menurut Larreche, Walker, Boyd (2009 : 21), yaitu marketing mix merupakan campuran variabel-variabel pemasaran yang dapat diatur oleh manajer guna menjalankan rencana aktivitas pemasaran dalam upaya untuk mendapatkan tujuan perusahaan di dalam sasaran pasar tertentu.

\section{Pengertian Produk}

Persaingan menuntut perusahaan untuk melakukan perubahan orientasi terhadap cara mereka melayani konsumennya, menangani pesaing dan mengeluarkan produk. Tingginya tingkat persaingan yang terjadi menuntut perusahaan untuk mempunyai strategi yang tepat dalam mencapai tujuannya serta memacu perusahaan untuk semakin inovatif dalam mengeluarkan produk yang sekiranya disukai konsumen. Produk yang memiliki angka merupakan prodak yang mempunyai bobot yang bisa memdapatkan kontribusi lebih terhadap suatu bentuk pemenuhan kebutuhan dan keinginan pelanggan. Pelanggan akan terus berusaha bisa memenuhi kebutuhannya dan mendapatkan manfaat dari suatu 
Vol. 6, No.3, September 2020, 213-221

produk, serta pelanggan akan memikirkan prodak mana yang bisa dipakai guna memenuhi kebutuhan dan dapat memberikan manfaat bagi mereka. Menurut Kotler dan Keller (2009 : 4), barang yaitu segala sesuatu yang bisa di tawarkan kepada pasar guna dapat memuaskan suatu kemauan dan keinginan, tarmasuk barang fisik, jasa, pengalaman, acara, orang, tempat, property, organisasi, informasi, dan ide.

\section{METODE PENELITIAN}

\section{Tipe Penelitian}

Tipe penelitian ini merupakan penelitian deskriptif kausal. Tipe penelitian deskriptif dilakukan untuk membuat deskripsi atau gambaran secara sistematis dan akurat mengenai fakta-fakta yang akan diteliti. Menurut Gay dalam Umar (2005 : 21) bahwa metode riset deskriptif bertujuan untuk menjawab pertanyaan menyangkut sesuatu pada waktu berlangsungnya riset.

\section{Lokasi penelitian}

Lokasi Penelitian akan dilaksanakan di Kota palu yang merupakan salah satu tempat pemasaran Oli pelumas Jumbo Power Internasional dan memiliki kantor cabang pemasaran yang berada di Jalan I Gusti Ngurahrai, No. 65 Palu Sulteng. Kantor ini bergerak dibidang distributor produk-produk yang di Produksi Perusahaan inti PT. Jumbo Power Internasional.

\section{Jenis Dan Sumber Data}

Untuk mengumpulkan data dalam penelitian ini, peneliti menggunakan beberapa teknik yaitu :

a. Observasi (pengamatan).

b. Interview (wawancara).

c. Kuisioner (angket).

d. Dokumentasion (dokumentasi).

\section{Populasi Dan Sampel.}

Populasi menurut Sugiyono (2014:115) mengemukakan populasi adalah wilayah generalisasi yang terdiri dari objek atau subyek yang mempunyai kuantitas dan karakteristik tertentu yang ditetapkan oleh peneliti untuk dipelajari dan kemudian ditarik kesimpulannya.

Menurut Ali dalam Tukiran dan Hidayati (2014:34) menyebutkan, bahwa sampel penelitian adalah sebagian yang diambil dari keseluruhan obyek yang diteliti yang dianggap mewakili terhadap seluruh populasi dan diambil dengan menggunakan teknik tertentu.

\section{Metode Analisis Data}

\section{Uji Validias}

Suatu skala pengukuran disebut valid bila ia melakukan apa yang seharusnya dilakukan dan mengukur apa yang harus diukur (Kuncoro, 2003 : 151). Untuk mengetahui apakah instrument itu valid, dilakukan uji validitas dengan menggunakan kesahihan butir dengan teknik korelasi produk moment (Momen Tangkar).

\section{Uji Reliabilitas}

Menurut Sudjana dalam Tukiran dan Hidayati (2014 : 43), memberikan definisi bahwa reliabilitas alat penilaian adalah ketepatan atau keajekan alat tersebut dalam menilai apa yang dinilainya. Artinya kapan pun alat penilai tersebut akan digunakan akan memberi nilai yang relatif sama. Pengukuran ini dapat di lakukan dengan menggunakan teknik Cronboch's Alpha (a) yang didasarkan pada kolersi b dalam instrumen pengukuran. Suatu instrument dikatakan reliable jika mempunyai nilai koefisien nilai cronboch's Alpha $(\alpha)$ lebih besar dari $0,6(\alpha \geq 0,6)$. 


\section{uji asumsi klasik}

Pengujian hipotesis dalam penelitian ini menggunakan model regresi linier berganda sehingga data yang digunakan harus memenuhi asumsi klasik yang pengujiannya sebagai berikut :

\section{Uji Normalitas}

Normalitas bertujuan menguji apakah dalam sebuah model regresi, variabel dependen (terikat), variabel independen (bebas), atau keduanya mempunyai distribusi normal atau tidak. Deteksi normalitas dilakukan dengan melihat penyebaran data (titik) pada sumbu diagonal dari grafik.

\section{Uji Multikolinieritas}

Uji multikolinearitas untuk mengetahui apakah variabel-variabel bebas (independen) yang diteliti tidak saling berkorelasi atau tidak terdapat hubungan yang signifikan diantara variabel independen. Gejala multikolinieritas dapat dilihat dari nilai VIF (Variance Inflation Factor) yang tinggi pada variabel-variabel bebas dalam suatu model regresi. Apabila nilai VIF lebih besar dari 10 maka hasil ini menunjukkan adanya gejala multikolinieritas dalam suatu model regresi. Sedangkan apabila nilai VIF lebih kecil dari 10 maka berarti tidak ada gejala multikolinieritas dalam suatu model regresi.

\section{Uji Heterokedastisitas}

Salah satu bentuk asumsi klasik adalah heteroskedastisitas, yaitu distribusi probabilitas gangguan yang dianggap tetap untuk seluruh nilai variabel bebas. Jika asumsi ini tidak terpenuhi maka terjadi masalah heteroskedastisitas, yaitu seluruh faktor gangguan tidak memiliki varian yang sama atau terdapat varian yang tidak konsisten untuk seluruh nilai variabel bebasnya. Bila ditemukan bahwa nilai korelasi diantara variabel-variabel independen dengan variabel ganggun (residual) melebihi tingkat kepercayaan $95 \%$ atau nilai signifikansi korelasi dibawah nilai $\alpha=0,05$ maka dinilai telah terjadi masalah heteroskedastisitas pada data hasil model regresi sehingga variabel-variabel independen tersebut mengandung nilai bias dalam memberikan hasil pengukurannya.

\section{Metode Analisis}

Analisis Regresi Linier Berganda digunakan untuk mengukur pengaruh beberapa variabel bebas (independen) terhadap suatu variabel terikat (dependen). Model umum persamaan Regresi Linear Berganda menurut Kurniawan (2014:194) sebagai berikut :

$\mathrm{Y}=\mathrm{a}+\mathrm{b}_{1} \mathrm{X}_{1}+\mathrm{b}_{2} \mathrm{X}_{2}+\mathrm{b}_{3} \mathrm{X}+\ldots \ldots+\mathrm{b}_{\mathrm{n}} \mathrm{X}_{\mathrm{n}}+\mathrm{e}$

Dimana :

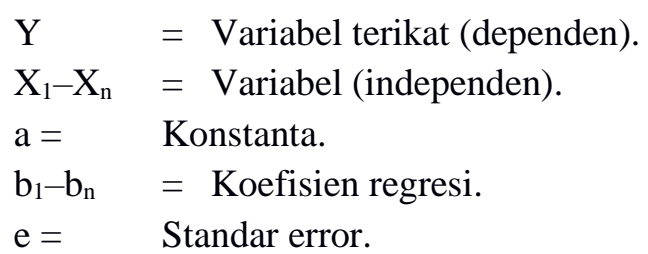

Bila rumus tersebut digunakan dalam penelitian ini, maka persamaan Regresi Linear Berganda yang diperoleh adalah :

$$
Y=a+b_{1} X_{1}+b_{2} X_{2}+b_{3} X_{3}+b_{4} X_{4}+b_{5} X_{5}+b_{6} X_{6}+b_{7} X_{7}+e
$$

Dimana :

$$
\begin{array}{lrl}
\mathrm{Y} & =\text { keputusan } & \mathrm{a}=\text { Konstanta. } \\
\mathrm{X} 1=\text { kinerja } & \mathrm{b} 1=\text { koefisien regresi kinerja } \\
\mathrm{X} 2=\text { kehandalan } & \mathrm{b} 2=\text { koefisien regresi kehandalan } \\
\mathrm{X} 3=\text { daya tahan } & \mathrm{b} 3=\text { koefisien regresi daya tahan } \\
\mathrm{X} 4=\text { estetika } & \mathrm{b} 4=\text { koefisien regresi estetika }
\end{array}
$$


Vol. 6, No.3, September 2020, 213-221

X5 = kualitas yang dipersepsika

$\mathrm{X} 6=$ keistimewaan tambahan

b5 = koefisien regresi kualitas yang dipersepsika

$\mathrm{X} 7=$ keseuaian spesifikasi

b6 $=$ koefisien regresi keistimewaan tambahan

b7 = koefisien regresi keseuaian spesifikasi

$\mathrm{e}=$ Standar Error.

\section{Pengujian Secara Simultas Untuk Hipotesis Pertama ( Uji F )}

Uji Serempak (Uji F) digunakan untuk menguji keberartian variabel bebas (independen) secara serempak terhadap variabel terikat (dependen). Untuk menentukan nilai $\mathrm{F}$ digunakan rumus sebagai berikut (Sugiyono, 2005:218) :

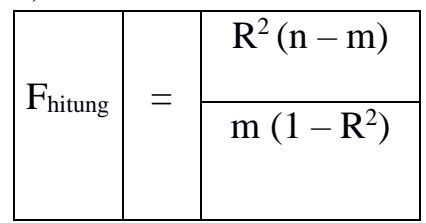

Dimana : $\mathrm{F}_{\text {hitung }}=$ Nilai $\mathrm{F}$ yang dihitung.

$\mathrm{R}^{2} \quad=$ Koefisien korelasi ganda.

$\mathrm{m}=$ Jumlah variabel independen.

$\mathrm{n} \quad=$ Jumlah responden.

Adapun kaidah pengambilan keputusan yang digunakan untuk menginterprestasikan hasil pengujian sebagai berikut :

a. Jika $F_{\text {hitung }} \geq F_{\text {tabel }}$ pada tingkat kepercayaan $(\alpha=95 \%) 95 \%(\alpha=0,05)$ maka terbukti bahwa semua variabel bebas (independen) secara serempak berpengaruh signifikan terhadap variabel terikat (dependen). Dengan kata lain, menolak hipotesis alternatif (Hi) dan menerima hipotesis awal (Ho).

Jika $F_{\text {hitung }}<\mathrm{F}_{\text {tabel }}$ pada tingkat kepercayaan 95\% $(\alpha=0,05)$ maka terbukti bahwa semua variabel bebas (independen) secara serempak berpengaruh signifikan terhadap variabel terikat (depeden). Dengan kata lain, menerima hipotesis alternatif (Hi) dan menolak hipotesis awal (Ho).

\section{Pengujian Secara Simultas Untuk Hipotesis Kedua Sampai Ke Tuju ( Uji T )}

a. Jika $t_{\text {hitung }} \geq t_{\text {tabel }}$ pada tingkat kepercayaan $95 \%(\alpha=0,05)$ maka terbukti varibel bebas (Xi-X7) secara parsial berpengaruh signifikan terhadap variabel terikat $(Y)$. Dengan kata lain, menolak hipotesis alternatif (Hi) dan menerima hipotesis awal (Ho).

b. Jika thitung $<t_{\text {tabel }}$ pada tingkat kepercayaan $95 \%(\alpha=0,05)$ maka terbukti variabel bebas (Xi-X7) secara parsial berpengaruh signifikan terhadap variabel terikat $(Y)$. Dengan kata lain, menerima hipotesis alternatif (Hi) dan menolak hipotesis awal (Ho).

\section{ANALISIS DAN PEMBAHASAN}

\section{Deskriptif Responden}

Karakteristik responden ini menyangkut beberapa ciri yaitu jenis kelamin, usia, pekerjaan, tingkat pendapatan perbulan dan konsumen yang melakukan pembelian produk PT. Jumbo Power Internasional cabang Kota Palu. Hal tersebut dimaksudkan untuk menjelaskan sedikit mengenai latar belakang responden dalam penelitian ini. Untuk lebih jelasnya masing-masing karakteristik tersebut dapat dilihat dibawah ini:

\section{Jenis Kelamin}

Berasarkan jenis kelamin yang diperoleh dari jumlah 120 responden yang mendominasi melakukan pembelian pada produk oli PT. Jumbo Power Internasional yaitu laki-laki berjumlah 83 dengan persentase $69.2 \%$ dan sisa dari pembelian berjenis kelamin perempuan berjumlah 37 dengan persentase $30.8 \%$. 
Vol. 6, No.3, September 2020, 213-221

Usia

Berasarkan jenis usia yang diperoleh dari jumlah 120 responden yang mendominasi melakukan pembelian pada produk oli PT. Jumbo Power Internasional yaitu 17-22 tahun sebanyak 37 dengan persentase 30,8\%, 23-28 tahun sebanyak 21 dengan persentase 17,5\%, 29-34 tahun sebanyak 28 dengan persentase $23,3 \%, 35-40$ tahun sebanyak 24 dengan persentase $20,0 \%$, dan $>40$ tahun sebanyak 10 dengan persentase $8,3 \%$.

\section{Pekerjaan}

Berasarkan jenis perkejaan yang diperoleh dari jumlah 120 responden yang mendominasi melakukan pembelian pada produk oli PT. Jumbo Power Internasional yaitu pelajar/mahasiswa sebanyak 41 dengan persentase $34,2 \%$, pegawai swasta sebanyak 31 dengan peersentase 25,8, wiraswasta sebanyak 25 dengan persentase 20,8\%, dan PNS sebanyak 23 dengan persentase 19,2\%.

\section{Pendapatan}

Berasarkan jenis tingkat pendapatan yang diperoleh dari jumlah 120 responden yang mendominasi melakukan pembelian pada produk oli PT. Jumbo Power Internasional yaitu Rp.500.000,-Rp.1.000.000 sebanyak 40 orang dengan persentase 33,3\%, Rp.1.100.00,-2.500.000 sebanyak 21 orang dengan persentase 17,5\%, Rp.2.600.000,-3.000.000 sebanyak 25 orang dengan persentase 20,8\%, dan $>$ Rp.3.000.000 sebanyak 34 orang dengan persentase $28,3 \%$.

\section{Hasil Analisis Regresi Linear Berganda}

Model analisis regresi linear berganda digunakan untuk mengetahui pengaruh kualitas produk (Kinerja, Kehandalan, Daya Tahan, Estetika, Kualitas yang dipersepsikan, Keistimewaan tambahan, Kesesuaian dengan spesifikasi) terhadap keputusan konsumen. Dalam menjawab permasalahan dan menguji hipotesis dalam penelitian ini digunakan alat analisis statistik regresi linear berganda (Multiple Linear Regresion) dengan menggunakan SPPS 22. Selanjutnya dapat dilihatpada Tabel 5.16 berikut ini:

Tabel 5.16

Rekapitulasi Hasil Uji Regresi

\begin{tabular}{|c|c|c|c|c|c|c|}
\hline \multicolumn{2}{|c|}{ Model } & \multicolumn{2}{|c|}{$\begin{array}{c}\text { Unstandardized< } \\
\text { Coefficients }\end{array}$} & \multirow{2}{*}{$\begin{array}{c}\begin{array}{c}\text { Standardized } \\
\text { Coefficients }\end{array} \\
\text { Beta }\end{array}$} & \multirow[t]{2}{*}{$\mathrm{T}$} & \multirow[t]{2}{*}{ Sig } \\
\hline & & B & Std. Error & & & \\
\hline \multirow[t]{8}{*}{1} & $($ Constant $)(\mathrm{Y})$ & .868 & .347 & & 2.505 & .014 \\
\hline & Kinerja (X1) & .261 & .054 & .304 & 4.827 & .000 \\
\hline & Kehandalan (X2) & .137 & .062 & .149 & 2.226 & .028 \\
\hline & Daya Tahan (X3) & .133 & .067 & .133 & 1.983 & .050 \\
\hline & Estetika (X4) & .119 & .049 & .116 & 2.413 & .017 \\
\hline & $\begin{array}{l}\text { Kualitas yang } \\
\text { Dipersepsikan(X5) }\end{array}$ & .991 & .087 & .972 & 11.425 & .000 \\
\hline & $\begin{array}{l}\text { Keistimewaan } \\
\text { tambahan (X6) }\end{array}$ & .173 & .065 & .229 & 2.651 & .009 \\
\hline & $\begin{array}{l}\text { Kesesuaian dengan } \\
\text { Spesifikasi (X7) }\end{array}$ & .177 & .063 & .187 & 2.814 & .006 \\
\hline \multicolumn{3}{|c|}{ R Square $\left(R^{2}\right)$} & $=0.756$ & F-Hitung & & $=49.650$ \\
\hline \multicolumn{3}{|c|}{ Adjusted R Square } & $=0.741$ & Konstanta & & $=0.868$ \\
\hline \multicolumn{3}{|c|}{ Multiple R } & $=0.870$ & Sig.F & & $=0.000$ \\
\hline
\end{tabular}

Sumber: data di olah

Hasil analisis regresi linear berganda dalam Tabel 5.16 di atas, kemudian dimasukkan kedalam model persamaan regresi linear berganda berikut:

$$
\begin{aligned}
& Y=0,868+0,261 X_{1}+0,137 X_{2}+0,133 X_{3}+0,119 X_{4}+0,991 X_{5}+0,173 X_{6}+ \\
& 0,177 X_{7}
\end{aligned}
$$


Vol. 6, No.3, September 2020, 213-221

Berdasarkan regresi linear berganda tersebut, dapat dijelaskan sebagai berikut:

a. Nilai konstanta a adalah 0,868 yang menunjukkan bahwa variabel kinerja, kehandalan, daya tahan, estetika, kualitas yang dipersepsikan, keistimewaan tambahan, kesesuaian dengan spesifikasi $\left(\mathrm{X}_{1}, \mathrm{X}_{2}, \mathrm{X}_{3}, \mathrm{X}_{4}, \mathrm{X}_{5}, \mathrm{X}_{6}, \mathrm{X}_{7}\right)$ berpengaruh positif terhadap variabel keputusan konsumen (Y). Berarti jika variabel kinerja, kehandalan, daya tahan, estetika, kualitas yang dipersepsikan, keistimewaan tambahan, kesesuaian dengan spesifikasi berubah/konstan $\left(X_{1}, X_{2}, X_{3}, X_{4}, X_{5}, X_{6}, X_{7}=0\right)$ maka keputusan konsumen akan meningkat pula.

b. Nilai koefisien regresi $b_{1}, b_{2}, b_{3}, b_{4}, b_{5}, b_{6}, b_{7}$, meningkat dari nilai yang di tetapkan yang menunjukkan bahwa variabel kualitas produk berpengaruh positif terhadap keputusan konsumen. Berarti jika variabel kualitas prouk meningkatkan maka keputusan konsumen akan meningkat pula.

\section{Pengujian Hipotesis Pertama (Uji Silmultan/Uji F)}

Pengujian hipotesis pertama yaitu untuk mengetahui pengaruh secara simultan antara Kinerja, Kehandalan, Daya Tahan, Estetika, Kualitas Yang Dipersepsikan, Keistimewaan Tambahan, Kesesuaian Dengan Spesifikasi terhadap keputusan konsumen melakukan pembelian pada produk oli produksi PT. Jumbo Power Internasioanal dengan taraf signifikan 0,05 (5\%).

Berdasarkan perhitungan menunjukan bahwa angka F-hitung sebesar 49.650 dengan tingkat signifikan 0,000 < a 0,05. Maka Ho ditolak dan Ha diterima. Artinya Variabel Kinerja, Kehandalan, Daya Tahan, Estetika, Kualitas Yang Dipersepsikan, Keistimewaan Tambahan, Kesesuaian Dengan Spesifikasi secara serempak berpengaruh terhadap keputusan konsumen melakukan pembelian produk oli produksi PT. Jumbo Power Internasional cabang Kota Palu.

\section{Pengujian Hipotesis Secara Parsial (Uji T)}

Pengujian hipotesis secara parsial digunakan untuk menguji pengaruh dari masing-masing variabel bebas secara parsial terhadap variabel $(\mathrm{Y})$, berikut penjelasan untuk masing-masing hasil uji $\mathrm{t}$ untuk setiap variabel independen:

Merujuk pada pada tabel 5.16 maka dapat disimpulkan sebagai berikut:

Dari variabel kualitas produk kinerja (X1), kehandalan (X2), daya tahan (X3), estetika (X4), kualitas yang dipersepsikan (X5), keistimewaan tambahan (X6), kesesuaian dengan spesifikasi (X7) berpengaruh terhadap keputusan konsumen dalam membeli produk oli produksi PT. Jumbo Power Internasional di Kota Palu.

\section{KESIMPULAN DAN SARAN}

\section{Kesimpulan}

Dari hasil penelitian diatas dapat ditarik kesimpulan sebagai berikut :

Dari variabel kualitas produk kinerja (X1), kehandalan (X2), daya tahan (X3), estetika (X4), kualitas yang dipersepsikan (X5), keistimewaan tambahan (X6), kesesuaian dengan spesifikasi (X7), baik secara simultan maupun parsial berpengaruh signifikan terhadap keputusan konsumen dalam membeli produk oli produksi PT. Jumbo Power Internasional di Kota Palu.

\section{Saran}

Berdasarkan kesimpulan yang dapat ditarik dari uraian dan pembahasan pada bab-bab sebelumnya maka penulis memberi saran yang bermamfaat untuk meningkatkan kualitas produk pada PT. Jumbo Power Internasional sebagai berikut :

1. Bagi PT. Jumbo Power Internasional

Untuk PT. Jumbo Power Internasional harus memberikan perhatian lebih untuk variabel kualitas yang dipersepsikan yang terbukti memberikan pengaruh signifikan terhadap kualitas produk 
Vol. 6, No.3, September 2020, 213-221

sehingga dapat lebih meningkatkan keputusan konsumen dalam membeli produk oli produksi PT. Jumbo Power Internasional di Kota Palu.

2. Berdasarkan hasil uji regresi yang dilakukan, yang mana variabel kualitas yang dipersepsikan dengan indikator oli jumbo dikenal oleh masyarakat luas sehingga mudah ditemukan (X5.2) dengan nilai mean 4.13 yang memiliki nilai terendah dari indikator X5.1 dan X5.3. Maka dapat dikatakan oli jumbo kurang dikenal di masyarakat karena memiliki nilai mean terendah, langkah yang harus dilakukan pihak kantor PT. Jumbo Power Internasional lebih memperhatikan dari segi promosi yang harus lebih ditingkatkan lagi, agar produk oli tersebut bisa lebih di kenal luas oleh masyarakat kususnya masyarakat yang ada di Kota Palu.

3. Bagi Peneliti Lain

Berdasarkan kesimpulan variabel di atas, maka diperlukan peneliti lain yang mampu menjelaskan variabel-variabel lain yang mempengaruhi keputusan konsumen. Dan peneliti selanjutnya kiranya membuat indikator pertanyaan yang lebih baik lagi, agar hasil penelitiannya dapat memberikan kontribusi yang baik untuk pihak-pihak yang bersangkutan

\section{REFERENSI}

Ali, Tukiran dan Hidayati Mustafidah, 2014, Penelitian Kuantitatif : Sebuah Pengantar, Penerbit Alfabeta. Bandung,

Gospersz, Irawan, Dany dan Edwin Japarianto, 2013, Analisa Pengaruh Kualitas Produk Terhadap Loyalitas Melalui Kepuasan Sebagai Variabel Intervening Pada Pelanggan Restoran Por Kee Surabaya, Jurnal Manajemen Pemasaran Vol. 1, No. 2, 1-8.

Gay, Umar, Husein, 2005, Riset Pemasaran dan Perilaku Konsumen, Cetakan Keempat, Penerbit Jakarta Business Research Center. Jakarta,

Kotler, Philip Dan Kevin Lane Keller, 2009, Manajemen Pemasaran, Edisi Ketiga Belas, Jilid I dan Jilid II Penerbit Erlangga. Jakarta.

Kuncoro, Mudrajad, 2003, Metode Riset Untuk Bisnis Dan Ekonomi : Bagaimana Meneliti Dan Menulis Tesis, Penerbit Erlangga. Jakarta.

Setiadi, Nugroho J., 2010, Perilaku Konsumen: Perspektif Kontemporer Pada Motif, Tujuan, Dan Keinginan Konsumen, Penerbit Kencana. Jakarta.

Sugiyono, 2014, Metode Penelitian Kuantitatif, Kualitatif dan R\&D, Alfabeta. Bandung.

Sudjana, Tukiran, Hidayati, 2014, Kuantitatif : Sebuah Pengantar, Penerbit Alfabeta. Bandung, 